\title{
人工膝関節全置換術後患者における大腿四頭筋および ハムストリングスの膝関節角度別等尺性筋力の推移
}

\author{
Variations in the Isometric Quadriceps and Hamstrings Strength at Different Knee \\ Joint Angles and Points of Time after Total Knee Arthroplasty
}

\author{
眞田 祐太朗 ${ }^{1,3)}$ 大澤 傑 ${ }^{1,2)}$ 椎木 孝幸 ${ }^{1)}$ 今高 康詞 1 ) \\ Yutaro SANADA, RPT ${ }^{1,3)}$, Suguru OHSAWA, MD ${ }^{1,2)}$, TAKAYUKI SHIIKI, RPT ${ }^{1)}$, KoJI IMATAKA, RPT ${ }^{1)}$ \\ 1) Department of Rehabilitation, Yukioka Hospital: 2-2-3 Ukida, Kita-ku, Osaka-shi, Osaka 530-0021, Japan \\ ${ }^{2)}$ Department of Physical Therapy, Faculty of Health Science, Osaka Yukioka College of Health Science \\ 3) [Present] Department of Rehabilitation Center, Kobe Kaisei Hospital: 3-11-15 Shinohara Kita-machi, Nada-ku, Kobe-shi, \\ Hyogo 657-0068, Japan TEL +81 78-871-5201 E-mail: sanada.yutaro@gmail.com
}

Rigakuryoho Kagaku 32(4): 553-557, 2017. Submitted Mar. 13, 2017. Accepted Apr. 12, 2017.

\begin{abstract}
Purpose] To clarify variations in the isometric quadriceps and hamstrings strength at different knee joint angles and points of time within a 1-year period after total knee arthroplasty (TKA). [Subjects and Methods] In 14 patients, who had been diagnosed with knee osteoarthritis and undergone TKA, measurement was performed at 5 points: before and at 3 weeks and 3, 6, and 12 months after surgery. Using the multi-purpose muscle function testing system BIODEX, the muscle strength was measured at knee flexion angles of $30^{\circ}, 60^{\circ}$, and $90^{\circ}$ to calculate the peak torque/weight and hamstrings/quadriceps ratios. [Results] The quadriceps strength at knee flexion angles of $60^{\circ}$ and $90^{\circ}$ was significantly reduced at 3 weeks after compared with before surgery. At 12 months after surgery, it was significantly increased at knee flexion angles of $30^{\circ}$ and $60^{\circ}$. [Conclusion] The results suggest that the quadriceps strength at a knee flexion angle of $90^{\circ}$ decreases after TKA, and it takes a longer time to recover.
\end{abstract}

Key words: total knee arthroplasty, isometric muscle strength, knee joint angle

要旨：〔目的〕人工膝関節全置換術（TKA）後 1 年までの大腿四頭筋およびハムストリングスの膝関節角度別等尺性 筋力の推移を調査し, その推移を明らかにすることを目的とした。【対象と方法】変形性滕関節症と診断され, TKA を施行した 14 名とした。調査期間は術前, 術後 3 週，3 カ月，6 カ月，12 カ月とした。筋力測定には BIODEXを 用いて, 膝関節 $30^{\circ}, 60^{\circ}, 90^{\circ}$ 屈曲位におけるピークトルク体重比と H/Q 比を算出した。【結果〕大腿四頭筋筋力は, 術前に比べ術後 3 週では $60^{\circ}$ および $90^{\circ}$ 屈曲位で有意に低下し, 術後 12 カ月では $30^{\circ}$ および $60^{\circ}$ 屈曲位で有意に増 加した。〔結語〕TKA 後の大腿四頭筋筋力は膝関節 $90^{\circ}$ 屈曲位において低下し, 回復も遅延することが示唆された. キーワード：人工膝関節全置換術, 等尺性筋力, 膝関節角度

\footnotetext{
1) 行岡病院 リハビリテーション科：大阪府大阪市北区浮田2-2-3 ( ₹ 530-0021)

2) 大阪行岡医療大学 医療学部 理学療法学科

3) 現所属：神戸海星病院 リハビリテーションセンター：兵庫県神戸市灘区篠原北町 3-11-15 (⿳ 657-0068) TEL 078-871-5201 


\section{I.はじめに}

末期の変形性膝関節症（Knee Osteoarthritis：以下， 膝 OA）患者に対する, 現在に打ける最も効果的な治療 法は人工滕関節全置換術（Total Knee Arthroplasty：以 下，TKA）である，TKA は疼痛の改善と運動機能の向 上をもたらすものの, 術後早期には関節可動域 (Range of Motion：以下，ROM）制限や大腿四頭筋の筋力低下, 歩行や階段昇降などの運動機能低下が生じる ${ }^{1)}$. なかで も, 大腿四頭筋の筋力低下は顕著であり, 術後 1 力月で は術前に比べて約 50〜 60\%低下することが報告されて いる ${ }^{1-4)}$. Mizner ら ${ }^{3)}$ は, TKA 後患者を対象に大腿四 頭筋筋力, 疼痛, ROM と運動機能テストとの関連を術 後 6 力月まで 1 力月間隔で調查し, 大腿四頭筋筋力がす べての調查期間で最も相関の高い身体機能であったと報 告している. 加えて, TKA 後は大腿四頭筋だけでなく 八ムストリングスにも筋力低下が生じることが報告され て抢り ${ }^{4,5}$, , 大腿四頭筋抢よび八ムストリングスの筋力 強化は, 術後リハビリテーションに抄ける重要な課題で ある。

我々は TKA 後 3 力月に扮ける階段昇降能力に関連す る身体機能について, 関節角度別の大腿四頭筋筋力に着 目して検討した結果, 大腿四頭筋筋力は膝関節 $60^{\circ}$ およ び $90^{\circ}$ 屈曲位で相関を認めたものの, $30^{\circ}$ 屈曲位では相 関を認めなかったことを報告した ${ }^{5)}$ 。階段昇降時の膝関 節運動について, 昇り動作では約 $60^{\circ}$ 屈曲位から立脚中 期にかけて伸展し, 降り動作では約 $10^{\circ}$ 屈曲位から立脚 後期にかけ約 $90^{\circ}$ 屈曲位まで屈曲していく6. そして, 筋活動を反映するとされる関節モーメントの大きさは, 昇り動作では立脚初期, 降り動作では立脚後期に増加す ることが報告されている7)。すなわち, 階段昇降時に求 められる大腿四頭筋の筋力発揮は, 昇り動作降り動作と もに $60^{\circ}$ 屈曲位以上の深い関節角度であることが推測さ れる。 また, TKA 後の臨床的問題である膝伸展不全 (Knee Extension Lag：以下, Lag) も 8), 大腿四頭筋の 筋力低下が要因の一つとされている ${ }^{9}$. 一一方, Lag は座 位での滕伸展動作を滕最終伸展位まで行うことができな い現象であることから，主動作筋である大腿四頭筋に求 められる筋力発揮は, 深い関節角度よりも滕最終伸展域 に近い浅い関節角度であることが推察される。このよう に, TKA 後の臨床的問題点と大腿四頭筋筋力との関連 は膝関節角度に特異的である可能性が考えられる。した がって, これらの問題点の改善を図っていくためには, 各関節角度に扔ける大腿四頭筋筋力の推移を明らかにし、 膝関節角度別に介入すべき時期や期間を明確にすること で，効果的な運動療法を検討していく必要がある.

膝関節角度別の等尺性膝伸展 ・ 屈曲筋力の推移につい て, Silva ら 10) は TKA 後 2 年以上が経過した 32 膝を 対象に, 膝関節 $0^{\circ}$ から $90^{\circ}$ 屈曲位まで $15^{\circ}$ 間隔で調查し,
健康な 52 膝と比較検討した。その結果, TKA 群の滕伸 展・屈曲筋力は対照群に比べ有意に低值であったと報告 している。また，中木ら ${ }^{11)}$ は TKA を施行した 70 膝を 対象に, 膝関節 $30^{\circ}, 45^{\circ}, 60^{\circ}$ 屈曲位に打ける等尺性筋 力を術前から術後 5 週まで 1 週間隔で調查し, 深い関節 角度ほど術前の状態に回復するのに時間を要したと報告 している. しかしながら, 先行研究の限界として, Silva ${ }^{10)}$ の研究では対象者の術後経過年数が 2 年から 6 年までと一定でないこと, 横断研究であり術前からの 推移が不明であることが挙げられる。 また，中木ら ${ }^{11)}$ の研究では調查期間が術後 5 週と短期間であり, $60^{\circ}$ 屈 曲位を超える深い関節角度の推移も明らかになってい ない.

そこで本研究では，膝関節 $30^{\circ}, 60^{\circ}, 90^{\circ}$ 屈曲位にお ける大腿四頭筋抢よび八ムストリングスの膝関節角度別 等尺性筋力を術前から術後 1 年間縦断的に調查し, その 推移を明らかにすることを目的とした。

\section{II. 対象と方法}

\section{1. 対象}

対象は 2013 年 10 月から 2014 年 8 月に, 滕 OA を原 疾患とし, 当院にて TKAを施行した 14 名（女性 14 名, 年齢 $71.2 \pm 5.7$ 歳) とした（表 1). Kellgren-Lawrence 分類による術側の重症度評価は, 全例グレードIVで あった，非術側はグレードIVが 5 名，Iが 3 名, 片側 罹患が 2 名, TKA 施行済みが 4 名であった。取り込み 基準は内側型膝 OA である者, 同一術者による TKA で ある者, 術後 1 年の経過観察が可能であった者とし, 術 前にシルバーカーを利用していた者は，歩行の自立度が 大腿四頭筋筋力に影響を及ぼす 12$)$ こから, 対象から 除外した。

使用機種は Triathlon ${ }^{\circledR}$ CS（日本ストライカー社製）で， 手術は mini-midvastus approach で関節に達し, Modified

表 1 対象者のベースライン属性

\begin{tabular}{lcc}
\hline 性別 $(人)$ & 女性 $: 14$ & \\
年齢 $($ 歳 $)$ & $71.2 \pm 5.7$ & $(60 \sim 80)$ \\
身長 $(\mathrm{cm})$ & $153.0 \pm 5.2$ & $(146.0 \sim 165.0)$ \\
体重 $(\mathrm{kg})$ & $60.0 \pm 5.6$ & $(50.0 \sim 71.0)$ \\
BMI $\left(\mathrm{kg} / \mathrm{m}^{2}\right)$ & $25.7 \pm 3.0$ & $(20.2 \sim 30.1)$ \\
罹患期間 $($ 年 $)$ & $10.9 \pm 6.1$ & $(3 \sim 20)$ \\
FTA $\left(^{\circ}\right)$ & $185.3 \pm 3.6$ & $(178.5 \sim 191.0)$ \\
滕屈曲 ROM $\left(^{\circ}\right)$ & $128.2 \pm 11.0$ & $(110 \sim 145)$ \\
滕伸展 ROM $\left(^{\circ}\right)$ & $-8.9 \pm 6.6$ & $(-25.0 \sim 0)$ \\
TUG (秒) & $11.1 \pm 2.0$ & $(7.7 \sim 13.8)$ \\
\hline
\end{tabular}

平均值 \pm 標準偏差 (最小值 最大值). BMI : Body mass index, FTA : Femorotibial angle, TUG : Timed Up and Go test. 
gap techniqueで施行された。 また膝蓋骨は置換され, lateral release は施行されず，各コンポーネントはセメ ント固定された。術中は駆血圧 $300 \mathrm{mmHg}$ でターニケッ トが使用され，平均駆血時間は $109 \pm 13(95 \sim 141)$ 分， 平均出血量は $173 \pm 88(74 \sim 380) \mathrm{g}$ であった. 術後理 学療法は, 当院のクリニカルパスに準じて術後翌日から 段階的に介入し, 術後 3 週から 5 週での退院を目標に実 施した. 担当は 3 名の理学療法士から無作為に選出され， 担当間で実施内容に差が生じないように調整を行った。 術後の平均入院期間は $33.7 \pm 10.5(17 \sim 53)$ 日であっ た。退院後は主治医の外来診察と並行し，原則として術 後半年までは月 1 回, 半年以降は 3 カ月に 1 回の頻度 で実施した。対象者には本研究の趣旨と内容, データの 利用に関する説明を行い，書面にて参加の承諾を得た。 倫理的配慮として, 行岡病院倫理委員会の承認を得た (承認番号：H2605-003).

\section{2. 方法}

研究デザインは前向きコホート研究とした，対象者は 手術前日に入院し，入院日にベースライン調査を行った。

調査項目は性別, 年歯, 身長, 体重, Body mass index，罹患期間，大腿脛骨角（Femorotibial angle：以下 FTA), 膝屈曲・伸展 ROM, 大腿四頭筋およびハムスト リングスの等尺性筋力, Timed Up and Go test（以下, TUG）とした。さらに，追跡調査として術後 3 週， 3 カ 月， 6 力月，12 カ月に筋力を測定した.

筋力測定には，多用途筋機能評価運動装置 BIODEX SYSTEM 4 (Biodex Medical Systems 社製) を用いた。 動作は Isometric mode, 測定角度および順序は膝関節 $30^{\circ}, 60^{\circ}, 90^{\circ}$ 屈曲位とした。測定は 5 秒間の最大努力 による膝伸展・屈曲動作を 2 回実施し, モニター上の波 形から安定した筋力発揮が持続的に行えていることを確
認した，加えて，各測定後には測定中に感じた疼痛の程 度を問診した。なお，十分な筋力発揮が妨げられるよう な中等度以上の疼痛を訴えた者はいなかった。また，測 定は非術側から術側の順とし，各動作間は 10 秒，各関 節角度間は 60 秒の休憩を設けた。得られたピークトル ク值を体重で除したピークトルク体重比 $(\mathrm{Nm} / \mathrm{kg})$ を採 用し, その值から大腿四頭筋に対するハムストリングス の筋力比 (Hamstrings/Quadriceps ratio : 以下, H/Q 比) を算出した。 なお，術後の初回測定時期である 3 週の ROM は, 屈曲が平均 $119 \pm 4.0^{\circ}\left(115 \sim 125^{\circ}\right)$, 伸展が 全例 0 ○であった。

統計学的解析は, 術前後における膝関節角度別の大腿 四頭筋およびハムストリングスの等尺性筋力, H/Q 比の 推移を検討するため, 各測定期間のうち術前を対照群と したDunnett 法による多重比較を行った。統計ソフトは EZR version 1.35 13) を使用し，有意水準は 5\%とした。

\section{III. 結 果}

大腿四頭筋およびハムストリングスの筋力, $\mathrm{H} / \mathrm{Q}$ 比 の膝関節角度別の推移を表 2 に示す。大腿四頭筋筋力は 術前に比べ術後 3 週の $60^{\circ}$ 屈曲位 $(\mathrm{p}<0.05)$ および $90^{\circ}$ 屈曲位 $(\mathrm{p}<0.01)$ で有意に低下し, 術後 12 力月の $60^{\circ}$ 屈曲位 $(\mathrm{p}<0.05)$ で有意に増加した。また, $30^{\circ}$ 屈曲 位では術前に比べ術後 6 力月 $(\mathrm{p}<0.05)$ と 12 力月 $(\mathrm{p}<0.01)$ で有意に増加した。 ハムストリングスの筋力 は, 術前に比べ術後 3 週の $90^{\circ}$ 屈曲位 $(\mathrm{p}<0.01)$ で有 意に低下した。また, $30^{\circ}$ 屈曲位では術前に比べ術後 6 カ 月 $(\mathrm{p}<0.05)$ と 12 カ月 $(\mathrm{p}<0.01)$ で有意に増加した. $\mathrm{H} / \mathrm{Q}$ 比については，いずれも有意な差は認めなかった.

表 2 大腿四頭筋およびハムストリングスの筋力，大腿四頭筋に対するハムストリングスの筋力 $(\mathrm{H} / \mathrm{Q})$ 比の膝関節角度別の推移

\begin{tabular}{|c|c|c|c|c|c|}
\hline 膝関節角度 & 術前 & 術後 3 週 & 術後 3 力月 & 術後 6 力月 & 術後 12 力月 \\
\hline \multicolumn{6}{|c|}{ 大腿四頭筋筋力（Nm/kg） } \\
\hline $30^{\circ}$ & $0.53 \pm 0.18$ & $0.46 \pm 0.10$ & $0.59 \pm 0.11$ & $0.66 \pm 0.08^{*}$ & $0.76 \pm 0.12 * *$ \\
\hline $60^{\circ}$ & $0.86 \pm 0.24$ & $0.62 \pm 0.13^{*}$ & $0.84 \pm 0.25$ & $0.96 \pm 0.27$ & $1.12 \pm 0.25^{*}$ \\
\hline $90^{\circ}$ & $0.85 \pm 0.31$ & $0.44 \pm 0.08^{* *}$ & $0.69 \pm 0.19$ & $0.82 \pm 0.19$ & $0.95 \pm 0.23$ \\
\hline \multicolumn{6}{|c|}{ ハムストリングス筋力（Nm/kg） } \\
\hline $30^{\circ}$ & $0.45 \pm 0.16$ & $0.41 \pm 0.09$ & $0.54 \pm 0.12$ & $0.58 \pm 0.14^{*}$ & $0.61 \pm 0.14^{* *}$ \\
\hline $60^{\circ}$ & $0.41 \pm 0.15$ & $0.32 \pm 0.07$ & $0.43 \pm 0.08$ & $0.47 \pm 0.11$ & $0.48 \pm 0.09$ \\
\hline $90^{\circ}$ & $0.26 \pm 0.11$ & $0.11 \pm 0.05^{* *}$ & $0.20 \pm 0.09$ & $0.22 \pm 0.08$ & $0.28 \pm 0.07$ \\
\hline \multicolumn{6}{|l|}{$\mathrm{H} / \mathrm{Q}$ 比（\%） } \\
\hline $30^{\circ}$ & $86.2 \pm 29.5$ & $89.9 \pm 21.2$ & $93.8 \pm 24.2$ & $88.9 \pm 25.1$ & $82.2 \pm 24.3$ \\
\hline $60^{\circ}$ & $47.0 \pm 11.7$ & $52.2 \pm 9.9$ & $54.4 \pm 16.9$ & $51.1 \pm 15.1$ & $44.4 \pm 10.7$ \\
\hline $90^{\circ}$ & $32.2 \pm 11.2$ & $26.4 \pm 14.4$ & $28.9 \pm 12.1$ & $27.3 \pm 8.5$ & $29.7 \pm 5.0$ \\
\hline
\end{tabular}

平均值 \pm 標準偏差. $*: \mathrm{p}<0.05, * *: \mathrm{p}<0.01$. 


\section{IV. 考 察}

本研究の結果, 大腿四頭筋筋力は術後 3 週において膝 関節 $60^{\circ}$ および $90^{\circ}$ 屈曲位で術前に比べ有意に低下して いたが，30。屈曲位では有意な差を認めなかった。すな わち, 術後早期における大腿四頭筋の筋力低下は, $60^{\circ}$ 屈曲位以上の深い屈曲角度において生じることが明らか となった。 また， $30^{\circ}$ および $60^{\circ}$ 屈曲位では術後 3 力月， $90^{\circ}$ 屈曲位では術後 6 力月でおおよそ術前值まで回復し ていた。 そして $30^{\circ}$ 屈曲位では術後 6 カ月, $60^{\circ}$ 屈曲位 では術後 12 カ月で術前に比べ有意に増加していたが, $90^{\circ}$ 屈曲位では術後 1 年通じて有意な増加を認めなかっ た. 関節トルクである筋力はモーメントアームと筋張力 の積によって表され, 同じ関節であっても関節角度が変 化することで関節トルクは増減する ${ }^{14)}$. 大腿四頭筋の 等尺性筋力は, 膝関節 $75^{\circ}$ 屈曲位付近で最大となり膝伸 展に伴い減少していくが, $75^{\circ}$ 屈曲位の $15^{\circ}$ 前後である $60^{\circ}$ および $90^{\circ}$ 屈曲位では同程度の值を示すことが報告 されている10,15)。本研究でも, 術前においては $60^{\circ}$ お よび $90^{\circ}$ 屈曲位では同程度の值であったが, 術後は $60^{\circ}$ 屈曲位に比べ $90^{\circ}$ 屈曲位の方が, 術後 3 週で約 $29 \%, 3$ 力 月以降では約 15 〜 $18 \%$ 低值であった. Schacheら 16) のシステマティックレビューにおいて, TKA 後患者の 大腿四頭筋筋力は， 3 年が経過しても健常者に比べ低下 していることが示されている。またFarquharら 17)は, 膝関節 $90^{\circ}$ 屈曲位の大腿四頭筋筋力を術後 1 年ごとに 3 年まで調査し, 非術側に経年的な筋力低下を認めたもの の術側は一定であったと報告している。すなわち, TKA 後の大腿四頭筋筋力は永続的に回復し続けるわけ ではなく, 術後 1 年で一定の水準に達することが推測さ れる。これらをまとめると, TKA 後は膝関節 $90^{\circ}$ 屈曲 位の大腿四頭筋筋力に回復の遅延を認め, 術後 1 年では $60^{\circ}$ 屈曲位以下の浅い関節角度と同等の水準に達しない ことが示唆された.

本研究では，ハムストリングスの筋力は術後 3 週にお いて膝関節 $90^{\circ}$ 屈曲位で術前に比べ有意に低下し, 術後 6 カ月以降では $30^{\circ}$ 屈曲位で有意に増加していた。TKA 後におけるハムストリングスの筋力の術後回復率は, 大 腿四頭筋筋力の回復率と同様の傾向にあることが報告さ れており4), 本研究もこれを支持する結果となった。 こ れは大腿四頭筋とは異なり，TKAによってハムストリ ングスに直接侵襲が加わるわけではないことから，八ム ストリングスの筋力低下は大腿四頭筋の筋力低下に付随 して生じていると考える。また H/Q 比については, 術 後 1 年を通じて有意な差を認めなかった。膝関節の動的 安定性は, 適切な $\mathrm{H} / \mathrm{Q}$ に依存するとされている ${ }^{18)}$. Tan ら 19) は, 膝 OA 患者は健常者に比べ滕伸展・屈曲 筋力ともに有意に低下しているのに対し, H/Q 比に有 意な差は認めなかったことを報告している。 また，彼ら
の報告における健常者の H/Q 比は, 膝関節 $30^{\circ}$ 屈曲位 で約 $91 \% ， 60^{\circ}$ 屈曲位で約 44\%であり，末期の膝 OA 患者である本研究対象者の術前值も $30^{\circ}$ 屈曲位で約 $86 \% ， 60^{\circ}$ 屈曲位で約 $47 \%$ と近い值であった。すなわち, 膝 OA 患者には大腿四頭筋だけでなくハムストリングス にも同程度の筋力低下が生じ, H/Q 比は健常者と変わ らないことが推察される。これらをまとめると, TKA 後におけるハムストリングスの筋力強化は, 大腿四頭筋 筋力の回復の程度に応じて実施していく必要があると考 えられる。

本研究の限界として, 対象者数が 14 名と少ないこと が挙げられる。 また対象者の罹患関節および非術側の重 症度を統一できていないため, 筋力の推移にどの程度影 響を与えているかは不明である。さらに手術は全例 mini-midvastus approach で施行されたことから, 従来法 を含む他の展開法による TKA 後患者と比較する際には 注意が必要である。このほか, 対照群を設けていないた め, 健常者と比較した筋力の程度は言及できないことも 挙げられる。 そして膝関節 $90^{\circ}$ 屈曲位に特異的で持続的 な大腿四頭筋の筋力低下を認めたものの, その要因につ いては明らかにできていない.

今後の課題として, より多くの症例を対象とした術後 1 年以上の縦断研究において対照群との比較検討を行い, 筋力回復の目標值を示していく必要がある.さらには, 筋力低下の要因を解明するとともに, 介入研究を行い適 切な理学療法を提供するための根拠を示していく必要が あると考える。

本研究では, TKA 後 1 年までの大腿四頭筋および八 ムストリングスの膝関節角度別等尺性筋力の推移を縦断 的に調查した，結果より，大腿四頭筋筋力は膝関節 $90^{\circ}$ 屈曲位において低下し回復も遅延することが示唆され た。本研究で得られた知見は，大腿四頭筋筋力が関連す る臨床的問題点の改善を図るための, 効果的な運動療法 を検討するための一助となると考えられる.

\section{引用文献}

1) Bade MJ, Kohrt WM, Stevens-Lapsley JE: Outcomes before and after total knee arthroplasty compared to healthy adults. J Orthop Sports Phys Ther, 2010, 40: 559-567.

2) Stevens JE, Mizner RL, Snyder-Mackler L: Quadriceps strength and volitional activation before and after total knee arthroplasty for osteoarthritis. J Orthop Res, 2003, 21: 775-779.

3) Mizner RL, Petterson SC, Snyder-Mackler L: Quadriceps strength and the time course of functional recovery after total knee arthroplasty. J Orthop Sports Phys Ther, 2005, 35 : 424-436.

4) Stevens-Lapsley JE, Balter JE, Kohrt WM, et al.: Quadriceps and hamstrings muscle dysfunction after total knee arthroplasty. Clin Orthop Relat Res, 2010, 468: 2460-2468. 
5) 眞田祐太朗, 椎木孝幸, 今高康詞・他：人工膝関節全置換 術後患者における階段昇降に関連する身体機能の検討。日 本人工関節学会誌, 2016, 46: 49-50.

6) McClelland JA, Feller JA, Menz HB, et al.: Patterns in the knee flexion-extension moment profile during stair ascent and descent in patients with total knee arthroplasty. J Biomech, 2014, 47: 1816-1821.

7) 山本澄子：関節モーメントの歩行分析. 医歯薬出版, 東京, 1997, p13.

8) 眞田祐太朗, 境 隆弘, 小柳磨敦・他: 人工膝関節全置換 術後の膝伸展不全と術前の膝伸展制限との関連性. 理学療 法科学, 2017, 32: 11-15.

9) 市橋則明：運動療法学 障害別アプローチの理論と実際, 第2版. 文光堂, 東京, 2014, p233.

10) Silva M, Shepherd EF, Jackson WO, et al.: Knee strength after total knee arthroplasty. J Arthroplasty, 2003, 18: 605-611.

11) 中木哲也, 橋本亮二, 神戸晃男 - 他 : 人工膝関節全置換 術における術後早期の筋力回復の推移について：BIODEX system 3 によるIsometric modeでの測定. 石川県理学療法 学雑誌, 2011, 11: 25-27.

12) 西島智子, 小山理惠子, 内藤郁奈 ·他：高齢患者におけ る等尺性膝伸展筋力と歩行能力との関係. 理学療法科学, 2004, 19: 95-99.

13) Kanda Y: Investigation of the freely available easy-to- use software 'EZR' for medical statistics. Bone Marrow Transplant, 2013, 48: 452-458.

14) 市橋則明：筋力トレーニングの基礎知識一筋力に影響する 要因と筋力増強のメカニズム一. 京都大学医療技術短期大 学部紀要別冊健康人間学, 1997, 9: 33-39.

15) 市橋則明, 日高正已, 浦野由紀子 - 他：脚伸展動作と膝 伸展動作の運動学的分析：Closed Kinetic Chain と Open Kinetic Chainの違い. 理学療法学, 1997, 24: 341-346.

16) Schache MB, McClelland JA, Webster KE: Lower limb strength following total knee arthroplasty: A systematic review. Knee, 2014, 21: 12-20.

17) Farquhar S, Snyder-Mackler L: The Chitranjan Ranawat Award: The nonoperated knee predicts function 3 years after unilateral total knee arthroplasty. Clin Orthop Relat Res, 2010, 468: 37-44.

18) Campbell DE, Glenn W: Rehabilitation of knee flexor and knee extensor muscle strength in patients with meniscectomies, ligamentous repairs, and chondromalacia. Phys Ther, 1982, 62: 10-15.

19) Tan J, Balci N, Sepici V, et al.: Isokinetic and isometric strength in osteoarthrosis of the knee. A comparative study with healthy women. Am J Phys Med Rehabil, 1995, 74: 364-369. 